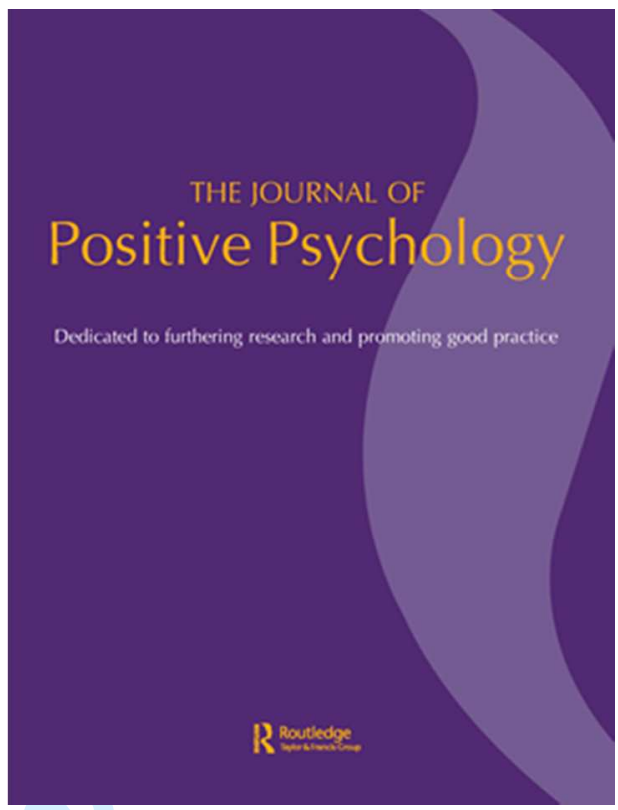

\title{
Well-being Vocabulary in Media Language: An Analysis of changing Word Usage in Norwegian Newspapers
}

\begin{tabular}{|r|l|}
\hline Journal: & The Journal of Positive Psychology \\
\hline Manuscript ID & RPOS-2015-0398 \\
\hline Manuscript Type: & Original Paper \\
\hline Date Submitted by the Author: & 14 -Dec-2015 \\
\hline Complete List of Authors: & $\begin{array}{l}\text { Carlquist, Erik; University of Oslo, Department of Psychology } \\
\text { Nafstad, Hilde; University of Oslo, Department of Psychology } \\
\text { Blakar, Rolv; University of Oslo, Department of Psychology } \\
\text { Ulleberg, På; University of Oslo, Department of Psychology } \\
\text { Delle Fave, Antonella; Università degli Studi di Milano, Department of } \\
\text { Pathophysiology and Transplantation } \\
\text { Phelps, Joshua; Bjørknes University College }\end{array}$ \\
\hline Keywords: & well-being, hedonism, eudaemonia, virtue \\
\hline Keywords (author supplied): & Media, Language, Trends \\
\hline & \multicolumn{2}{|c}{} \\
\hline
\end{tabular}

\section{SCHOLARONE"}

Manuscripts

URL: http:/mc.manuscriptcentral.com/rpos Email: journalpospsych@ucdavis.edu 


\section{Introduction}

The past several decades have witnessed an upsurge of interest in well-being. Besides becoming the topic of a burgeoning research field within psychology (Csikszentmihalyi \& Nakamura, 2011; Sirgy, 2012; Yen, 2010), well-being has also attracted increasing political attention (Diener, Lucas, Schimmack, \& Helliwell, 2009; Dolan \& Metcalfe, 2012) as well as popular interest (Madsen, 2015; Mathews \& Izquierdo, 2008). Ideas about what makes life worth living circulate in mass media nationally and internationally, reflecting and potentially reinforcing conceptualizations and experiences of personhood and well-being that characterize contemporary societies (Sointu, 2005). Public media play a framing and agendasetting role (Perse, 2001; Shah, McLeod, Gotlieb, \& Lee, 2009), with implications for everyday opinion as well as practice in fields such as social policy and health care. It is therefore important to investigate how ideas of a good life, as expressed in the public sphere, develop and change. The purpose of the present study was to identify and interpret temporal changes in well-being related language during the past two decades. Specifically, we have examined how Norwegian print news media have made use of specific key words related to established well-being theories and models. Evidence of clearly discernible frequency developments during this relatively short period of time could contribute to current debates on conceptualization and measurement of well-being phenomena, and dissemination of policyrelevant findings within positive psychology and the rapidly growing research field of wellbeing more generally.

\section{Well-being in everyday and scientific Discourse}

Any account of well-being will inevitably draw on prevailing assumptions or "cultural wisdoms" (Polkinghorne, 2000) regarding what a good life amounts to in a given social group or society. Although phenomena of living well are conceptualized in most - if not all cultures worldwide, considerable variation has been detected in how people conceptualize and think about well-being (Delle Fave, Brdar, Freire, Vella-Brodrick, \& Wissing, 2011; Gough, 2004; Lu, 2008; Pflug, 2009; Tiberius, 2004; Tov \& Diener, 2007; Uchida, Norasakkunkit, \& Kitayama, 2004; Valsiner, 2007; Wierzbicka, 2004). Furthermore, because cultures, nations and communities are dynamic entities undergoing development in complex ways (Inglehart \& Welzel, 2005; Lu, 2008), cultural wisdoms concerning human nature and well-being are inevitably characterized by change over time. Importantly, in late modern societies, outlooks 
on life are informed by scientific concepts and models derived from a variety of disciplines (Wagner, 2007).

A common representation of well-being in many Western societies today involves considering individual happiness as the ultimate objective or criterion of a good life (Duncan, 2010; Eckersley, 2000). In psychology and social sciences this view has given rise to a bulk of research focused on the construct of subjective well-being (SWB), conceptualized and measured as positive life evaluations (life satisfaction) in combination with a relative predominance of positive affect over negative affect (Diener, 2000). This hedonic perspective has been described as a "narrow" approach to well-being, while a "broader" approach draws on eudaimonic and humanistic accounts as well as philosophical conceptualizations of virtuous activity (Kashdan \& Steger, 2011; Nafstad, 2015; Peterson \& Seligman, 2004; Tiberius, 2013). Maintaining that hedonic pleasure constitutes merely one of several dimensions of a good life, the broader view includes dimensions such as hope, meaning, purpose, leading a balanced life and fulfilling needs for social belonging, autonomy and competence. Both the narrow and the broader lines of well-being research coexist in positive psychology (Joseph, 2015; Kashdan \& Steger, 2011). The present study takes key words of these two perspectives as a point of departure to explore the usage of related vocabulary in the media.

\section{Language, Words and shared Common Sense}

Social values and meaning systems are embedded in language and are reflected in the ways words and expressions are used (Bakhtin, 1981; Billig, 1997; Nafstad, Blakar, Carlquist, Phelps, \& Rand-Hendriksen, 2009; Rommetveit, 2003). Because words are understood through the lens of historically, culturally and locally developed meaning systems, longitudinal trajectories of recurrence and usage of a single word can serve as empirically available indicators of societal values and priorities (Blakar, 1979; Pennebaker, Mehl, \& Niederhoffer, 2003; Phelps, Blakar, Carlquist, Nafstad, \& Rand-Hendriksen, 2012). Insights concerning tacitly taken-for-granted assumptions in a society can therefore be obtained by studying various genres of texts. Mass media are particularly influential in this regard because they connect the individual with the wider macro-social assumptions and values (Castells, 2010; Jaworski, 2007). In recent decades, people have increasingly turned to the media to make sense of their worlds (McCombs \& Reynolds, 2009; Perse, 2001). Systematic empirical studies of language usage in the media can therefore shed light on the ongoing construction and development of cultural meaning systems, including common sense and normative ideas 
that guide how people think, feel and interact (Billig, 1991, 2006; Bruner, 1990; Fairclough, 2013; Nafstad, Carlquist, \& Blakar, 2012; Verschueren, 2012).

In the present study we have investigated temporal changes in the language representation of well-being through the analysis of the usage patterns of single words or expressions in Norwegian newspapers. The selected words were derived from vocabularies of both the "narrower" and "broader" perspectives within positive psychology.

\section{The Norwegian Context}

The Norwegian society, with a population of around 5 million, is currently characterized by a low level of income disparity, widespread welfare provision, gender equality, increasing multiculturality, and a high degree of civic engagement and voluntary participation (Carlquist, Nafstad, \& Blakar, 2007; Ellingsæter \& Leira, 2006; Sejersted \& Adams, 2011; Wollebæk \& Strømsnes, 2008). Newspaper readership in Norway is among the highest in the world, and it is reflected in a large number of local and regional newspapers (Østbye, 2007). Considerable regional variation can be detected at the historical, cultural and economic levels, in part due to the country's large and geographically varied territory. Similarly, distinct identities and dialects characterize different parts of the country (Gooskens, 2005). The south-eastern region is the most densely populated; it contains the largest agricultural areas and the capital Oslo, with its financial and administrative functions. The western region is characterized by maritime industries, as well as oil and gas production since the 1970s. The northern region was traditionally associated with fishery industries and Sami reindeer herding, but it underwent considerable change during the 1990s and 2000s due to new discoveries of oil and gas fields, and increasing trade and cultural contacts with Russia (Jensen \& Hønneland, 2011; Jones, 2008).

\footnotetext{
Aims of the Study

The aim of the current study is to contribute to the ongoing investigation of the concept of well-being in contemporary societies, by examining word use patterns in Norwegian media from the past two decades. Specifically, we investigated the occurrence and usage frequency across time of selected words related to four well-being perspectives: affective approaches focusing on feelings (Kahneman, 1999); cognitive or life satisfaction approaches focusing on evaluative assessments (Pavot \& Diener, 2008); eudaimonic and humanistic approaches focusing on functioning (Ryan \& Huta, 2009; Wong, 2012); and the virtue approach centered on character strengths (Peterson \& Seligman, 2004). For short, we
} 
will refer to these groups as the affective, evaluative, functional and virtue groups. For heuristic purposes, we have treated the affective and most of the evaluative words as belonging to the narrow view of well-being, while the functional and virtue words were subsumed under the broader view. Words related to good life and quality of life were included in the evaluative category, as quality of life in the Norwegian vocabulary is particularly related to subjective evaluations of well-being (Barstad, 2014).

Due to the dearth of comparable studies (see e.g., Nafstad, Blakar, \& RandHendriksen, 2009; Sointu, 2005), this study is explorative. Nevertheless, some expectations were formulated, based upon general cultural trends reported in sociological and psychological literature, and combined with the researchers' local knowledge of language use in Norway (Hellevik, 2008; Nafstad et al., 2013). In light of the internationally documented rise of individualism and attention towards the self (Beck \& Beck-Gernsheim, 2002; Schwartz, 2000; Twenge, Campbell, \& Gentile, 2013), we expected to detect an increasing occurrence of words related to affect and evaluation. Turning to the "broader" approaches, we expected to find variability in the usage of words concerning eudaimonic or functional facets of wellbeing, including a rise among words directly referring to the self. In regard to virtues, strong collaborative efforts and selfless hard work have traditionally been core values in the Norwegian society (Gullestad, 1991), but studies of recent developments point towards rising individualism and consumerism at the expense of communal values (Nafstad, Blakar, \& Rand-Hendriksen, 2009). On the basis of these trends, supported by a study documenting the decline of virtue words in books published in the United States during the $20^{\text {th }}$ century (Kesebir \& Kesebir, 2012), we expected the frequency of virtue words to fall also in Norwegian media.

\section{Method}

The present study draws on previously developed methods for examining longitudinal word usage patterns in media discourse (Nafstad, Blakar, Carlquist, Phelps, \& RandHendriksen, 2007; Nafstad, Blakar, Carlquist, et al., 2009; Phelps et al., 2012). Annual word frequency data were drawn from a database of electronically archived Norwegian newspapers (http://www.retriever.no). This online database generates a list of articles which satisfy specific search criteria such as a given word, a string of words, or combinations employing Boolean operators such as AND, OR and ANDNOT. Truncations are possible by means of asterisks (extensions) or question marks (alternative letter replacements). Frequency of occurrence was defined as the total annual number of articles including the specific search 
words. The exact duration of the period analysed (1992-2014) was determined in order to include several large newspapers that first became archived in the electronic database in 1992.

\section{Selection of Search Words}

A particular challenge involved in this method was to establish a suitable and relatively parsimonious profile of search terms. Although a vast pool of words can be used to describe well-being, we primarily sought to investigate common and theoretically relevant words and expressions related to well-being in everyday Norwegian vocabulary.

To capture core vocabulary of positive affect (Kahneman, 1999; Watson, Clark, \& Tellegen, 1988), the closest Norwegian equivalent of the following terms were chosen for analysis: enjoy, happy; happiness; interest; interested in; joy; joyful; and positive / good feelings. The word happiness is notably difficult to translate (Oishi, Graham, Kesebir, \& Galinha, 2013; Wierzbicka, 2004). The most common translation of the English term into academic Norwegian language is represented by the word "lykke” (cf. Hellevik, 2008; Lolle \& Andersen, 2015). Similar to the English word happiness, "lykke” can hold meanings beyond momentary affect. However, for the purposes of the present study, it was included among the positive affect words since its adjective form "lykkelig" in Norwegian clearly signifies an emotional state. Also of note are joy and joyful, which are equivalent to the very common Norwegian words "glede" and "glad", although the Norwegian words possibly connote somewhat lower levels of arousal than joy and joyfulness. The chosen Norwegian equivalent for enjoy, "nyte", can be said to connote pleasure, in addition to enjoyment. For negative affect (Kahneman, 1999; Watson et al., 1988), the following words were included: Anger; angry; frightened; grief; negative / bad feelings; sad; shame; and upset. For these words, the Norwegian meanings largely correspond to those of the English terms.

For evaluative words (Diener, 2000; Diener, Wirtz, et al., 2009; Pavot \& Diener, 2008), these terms were selected: contented; positive thoughts / think positive; satisfied; satisfaction; and satisfied with life / life satisfaction. Furthermore, for quality of life (Sirgy, 2012), the broader ranging expressions good life and quality of life were included in the evaluative group. We additionally included the literal Norwegian translation of well-being ("velveere"). In contrast to English, the Norwegian word has particular connotations of bodily pleasure and pampering.

Words in the functional (eudaimonic/humanistic) group were theoretically derived from the literature on psychological well-being (Ryff \& Singer, 2008), eudaimonic happiness (Delle Fave et al., 2011), self-determination theory (Ryan \& Deci, 2000) and meaning (Steger, 
Shin, Shim, \& Fitch-Martin, 2013; Wong, 2012). For this group, the following words and expressions were selected: inner calmness; meaningful; meaning-filled (reflecting an alternative Norwegian word for meaningful); master; mastery; motivation; self-realization; and self-development.

The selected virtue words were theoretically based on a list of major character strengths (Peterson \& Seligman, 2004, p. 29) and included wisdom; humanity; courageous; temperance; justice; gratitude and hope. The latter two terms were selected to signify the major virtue of transcendence, which could not be captured in a single, everyday term. For courage, a specific adjective ("modig") rather than the general noun had to be chosen, as the Norwegian noun form "mot" is a homonym also meaning "against" or "towards".

Determining searchable words posed several challenges. First, some words were of a general nature (e.g., belonging) and could thus not be included, as they also refer to phenomena unrelated to well-being. Second, certain expressions (e.g., self-acceptance) were not sufficiently prevalent in the Norwegian media language to permit inclusion in the analysis. Similar problems emerged when the signified phenomenon could not be easily distilled into a single word or expression in the Norwegian language. When possible, truncated (extended) words were chosen in order to obtain word combinations and therefore a larger number of articles implying increased statistical strength as well as wider conceptual meaning. However, many words held additional meanings irrelevant to well-being when truncated. As an example, the plural form of frightened (Norwegian "redde") is a homonym which also means "to rescue". In such cases, only the basic forms were retained, or the Boolean "ANDNOT" function was used to exclude frequently occurring meanings irrelevant to well-being. We also investigated both noun and adjective forms of certain words when there was reason to believe that they could develop differently. In other cases, only one of the grammatical forms was deemed to provide a valid search term. The selection of search words therefore involved pragmatic trade-offs between delimitation and inclusiveness.

\section{Selection of Newspapers}

The present study included several newspapers to capture regional and socio-cultural variation within the Norwegian society, since the aforementioned cultural diversity might have produced regional variation in the vocabulary of common sense as well as underlying assumptions about well-being. In contrast, previous social psychological analyses of language usage in Norwegian media (Nafstad et al., 2007; Nafstad, Blakar, Carlquist, et al., 2009; Phelps et al., 2012) aimed to cover a longer time span and therefore analyzed only one 
newspaper (Aftenposten) which was searchable back to 1984. Among Norwegian print media, the two largest national newspapers (Aftenposten, Verdens Gang) and two large regional newspapers (Bergens Tidende, Nordlys) were included. Whereas Aftenposten is generally recognized to be a broadsheet newspaper, Verdens Gang is considered somewhat more tabloid. The two regional newspapers cover the western and northern regions of the country, respectively. However, in addition to its national function, Aftenposten also serves as a regional newspaper for the Oslo (capital) area, which is located in the most densely populated south-eastern region of the country. The selection of newspapers was therefore considered to represent both regional and journalistic scope.

The article database for Nordlys included birth, death and birthday notes as from 2012, which was found to generate an overrepresentation of words such as "lykke". The analysis was therefore conducted only for the 1992-2011 period for this newspaper.

\section{Establishment of Baseline}

Because the annual numbers of published newspaper articles as well as article length vary across time, a baseline adjustment was performed to identify the usage trend of a given word. In previous studies, a correction based on the average annual number of published articles was used (Nafstad et al., 2007; Nafstad, Blakar, Carlquist, et al., 2009). Later studies further adjusted for the potential bias resulting from varying article length by using a baseline trend based on the 10,000 most frequently occurring Norwegian words (Nafstad et al., 2013; Phelps et al., 2012). However, correcting for a large number of frequent words requires that the editorial profile of the investigated newspaper is not subject to large changes, which was the case for at least one of the selected newspapers (Verdens Gang). A more elementary baseline was therefore employed, which correlated highly (annual indexes: $r=.99$ ) with the 10,000 word trend for Aftenposten, for which this correction was initially developed. For the baseline, average trends for ten assumed ideologically neutral words was derived, drawn from a database of common Norwegian words (Tekstlab, 2015). The revised baseline was found to perform well for all newspapers by producing a smoother reference trend than the 10,000 word trend. For Aftenposten, correlations between the annual frequencies of the ten words used for the baseline index ranged from 859 to. 994 (Pearson's $r$ ). For Bergens Tidende, frequencies correlated between .477 and .976 , and for Nordlys the corresponding values fell between .723 and 986. For Verdens Gang, greater dispersion between trends was observed, with correlations ranging from $.213(\mathrm{n} / \mathrm{s})$ to .981 . However, 37 of 45 word pairs showed correlations of 0.60 or above, and the index was deemed satisfactory. 


\section{Statistical Analysis}

Three-year moving averages were used to reduce the effects of extraordinary annual changes and particular events. As an example, certain affect words showed very high values in 2011, when Norway experienced a major terror attack, with considerable ramifications in mass media discourse (Andersson, 2012). Potential longer-term discursive effects of such events will nevertheless be captured by moving averages.

As an approximation of trend developments, a linear regression model was applied. An estimate of mean annual percentage change (EMAC) was calculated based on the slope of the regression line (see Nafstad et al., 2007; Nafstad, Blakar, Carlquist, et al., 2009 for further elaboration of this indicator). Strict criteria were used for hypothesis testing, as simply retaining any linear association showing a $p$ value under .05 as a significant finding would amount to "data fishing". We therefore employed a Bonferroni-corrected alpha level of 0.0013 to detect statistically significant associations with time, reflecting the number of repeated tests (i.e., .05/39 search terms). Viewing the newspapers together, a criterion was established requiring that at least three newspapers showed significant Bonferroni-corrected frequency trends in the same direction.

\section{Results}

Considerable variability was detected with regard to average annual frequencies of the well-being terms as well as trend developments among the four newspapers. We first examined affective terms. Among the positive emotion words, enjoy, joyful and the less frequent expression good / positive feelings significantly increased across at least three newspapers (see Table 1). Additionally, we observed that happiness increased in two newspapers and showed a borderline significant increase in a third (Bergens Tidende, $p$ $=.0015)$. Unexpectedly, both terms for interest declined in all newspapers. It is also of note that joy showed a significant change in three newspapers; however, while this word declined in two of them, it increased in Nordlys. Among the terms related to negative affect, only upset and sad showed significant increasing linear trends across newspapers. The EMAC was particularly strong for sad, ranging from $1.5 \%$ to over $4 \%$.

Among the evaluative expressions, only quality of life showed a significant increase in frequency across time in three newspapers (see Table 2). However, its average annual prevalence was low compared to the other words. The frequency of the general terms satisfied 
and satisfaction showed clear declines across newspapers, with negative EMACs in total ranging from $1.5 \%$ to $5 \%$.

Turning to the functional (eudaimonic-humanistic) group, we observed that the frequency of mastery rose significantly and sharply in all four newspapers, with the EMAC rate ranging from $10 \%$ to $14 \%$ (see Table 3). Motivation also showed increasing trends in all newspapers, characterized by annual average growth rates of between $3 \%$ and $5 \%$. Meaningful rose in three newspapers. Although less frequently used, self-realization showed significantly increased occurrence in three newspapers, with an annual average growth rate of over $5 \%$, while the frequency of self-development rose in all newspapers, with growth rates between $2 \%$ and 5\%. Among the virtue terms (see Table 4), hope and humanity showed significant diminishing frequencies in three newspapers. Contrary to expectations, the occurrences of courageous and gratitude increased in three newspapers.

\section{Discussion}

Our findings have several implications for well-being research and the field of positive psychology. The main picture emerging from the analysis is that media usage of words referring to individual well-being shows systematic and statistically significant patterns of change. These patterns were found despite the adoption of a stringent Bonferroni-corrected statistical significance criterion in at least three of the newspapers. Nineteen out of the thirtynine search terms were found to show significant changes across time, with evidence of both increasing and decreasing usage.

A general message derived from the analysis is therefore that well-being related terms in media discourse are not characterized by stable usage frequencies. Usage patterns of a word in a given society, and potentially its connotations, may change across time. Our findings demonstrate that even core vocabulary of well-being belongs to a changeable, culture- and rule-based field of linguistic practice (Wittgenstein, 1953). Changing practices, e.g., words becoming increasingly in vogue or obsolete, potentially reflect cultural or historical developments of theoretical and practical importance for positive psychology.

Findings do not unequivocally point toward increasing "happiology" (Seligman \& Pawelski, 2003) in the Norwegian media. As expected, a number of words associated with emotional conditions, life evaluations and functionality increased in frequency. However, the detected patterns did not consistently conform to expectations. Notably, with regard to the positive affect words, only enjoy, joyful and positive / good feelings became significantly more frequent across newspapers, although data provided some support for a rise of happiness 
also. The occurrence of other central affective and evaluative words within the "narrow" view of well-being was instead shown to decline, such as the unexpected case with the common word joy ("glede").The somewhat formal character of the term might explain why it has lost ground in an increasingly popularized print press. Strikingly, the occurrence of words related to interest (both interest generally, and circumscribed as interested in) declined considerably. This finding suggests that less directly denoting words might have been increasingly used to describe interest as a phenomenon (e.g., the detected rise of motivation). As an alternative or complementary explanation, this decline may reflect a diminishing media representation of the phenomenon of showing interest.

An intriguing pattern was observed in the frequency trend of the negative emotion words. In this group, only upset and sad showed the expected increase across time, while no significant trends emerged for the other negative affect words. Norwegian cultural norms have historically endorsed introversion rather than emotional display (cf. Eriksen, 1993), and one can speculate that the discursive presentation of sadness and upset might have been rendered gradually more acceptable than potentially more "troublesome" emotions of anger or shame.

A further intriguing finding is that both the adjective satisfied ("tilfreds") and the noun satisfaction ("tilfredshet") declined in frequency. This unexpected trend could be ascribed once again to the somewhat conservative quality of the terms in Norwegian, but also that this particular etymological framing, literally referring to "being at peace", sits ideologically at odds with a society expecting rapid social change and expectations of dynamic movement (Perrons, 2004) and showing signs of rising income inequality (Aaberge \& Atkinson, 2010). It is furthermore of note that the frequency of satisfaction with life / life satisfaction was low and did not significantly rise, while quality of life did.

The largest magnitude of change was found among the eudaimonic terms. The noun mastery, while already present in the Norwegian dictionary, was initially almost unused in the newspapers, but emerged as a word with rapidly increasing occurrence. This finding is of further interest because the verb to master, although more frequent, failed to display a similar change. Taken together, these usage trends suggest that concepts of mastery as achievement, rather than process, have become more salient. The frequency of self-development also increased sharply, and similar trends were detected for motivation and self-realization. On the one hand, these developments suggest that certain forms of eudaimonic functioning (Ryff \& Singer, 2008) have been promoted or increasingly reflected in the media. Somewhat in contrast, although no causal conclusions are warranted, this observation supports previous studies documenting an increasing attention to the refashioning of self and a constant 
requirement for self-improvement, associated with values of neoliberal capitalism (Türken, Nafstad, Blakar, \& Roen, 2015).

The increased occurrence of meaningful should be interpreted with care, since the alternative term meaning-filled declined in two newspapers and was borderline significant in a third (VG, $p=.0013$ ). Findings concerning meaning are therefore inconclusive as the combined frequency trends of these two words do not point in any clear direction. The general term meaning was not included in the pool of search words since it has multiple connotations, in Norwegian also including "opinion" and "intention". Taken together, these observations underscore particular conceptual difficulties involved in the empirical investigation of the construct, at least within the language of media (see also Leontiev, 2013).

Overall, the findings portray that media usage of well-being terms represents a surprisingly dynamic field of linguistic practice. A possible interpretation of the findings is that eudaimonic words particularly appear to be on the rise, while there is little evidence of "happiology". However, the findings cannot be uncritically generalized beyond the Norwegian context, as terminological usage is likely to show large variability across languages. Importantly, the observations are situated in a Scandinavian culture which might be particularly hesitant towards up-beat or abundant expression of affect. In general, the interpretations we have offered of the reported trends are post-hoc explanations that require further studies of connotative change across time.

\section{Limitations and Future Directions}

The objective of this study was not to capture the linguistic totality of well-being discourse in the media. Rather, we sought to examine the degree of stability or change for usage frequencies of selected core well-being terms. Therefore, the findings do not allow us to draw any conclusion concerning the increasingly or decreasingly salience of well-being issues in Norwegian public discourse. Findings are valid primarily for the specific search words and the context investigated. The analysis reveals that certain words, particularly mastery and selfdevelopment, have been rapidly taken up in Norwegian print media, suggesting that these words might serve particular ideological functions. It also demonstrates how the frequency of certain rather common words (e.g. satisfied, satisfaction) gradually decreased. However, our data do not address possible reasons for such trends. One the one hand, growing occurrence of certain well-being terms can be interpreted as an increased and liberating focus on individual opportunity (Seligman, 2011). On the other hand, rising usage of well-being terms might reflect neoliberal ideology in which seemingly empowering practices conceal increased 
corporate power and a gradual dismantling of welfare provision (Greco \& Stenner, 2013; Madsen, 2015). Further inquiry, particularly of a qualitative nature, is required to answer such questions.

Although a number of trends were found across several newspapers, findings suggest that social psychological analyses of media language can benefit from including a wide array of media sources. Since the 1990s, internet and social media have gained vast importance as channels of communication. The current analysis concerns printed media only, thus potentially overlooking trends in online media as well as television. The growth of digital media is furthermore likely to produce editorial changes in print media, partly as a consequence of declined readership and the increasing average age of newspaper readers.

More detailed and specific studies are required to examine the discursive development of circumscribed well-being components, such as emotions, evaluations, or eudaimonic functioning. The selection of words for the present study posed considerable challenges, as some key phenomena investigated in well-being research, such as meaning, cannot be fully captured by a single term. Although we aimed to minimize the use of ambiguous search terms, the selected search terms might be biased or insufficiently representative of the represented phenomenon. Furthermore, as meanings of psychological words are culturally contingent (Lolle \& Andersen, 2015; Oishi et al., 2013; Wierzbicka, 2009), great care must be taken when drawing cross-cultural conclusions. Local variation in the language of well-being underscores the necessity of increased research attention to culturally contextualized understandings and developmental trends of words in the psychological vocabulary. In spite of pervasive globalization, a variety of cultural norms and traditions still inform individual and social behaviors. Finally, findings suggest that even within a specific cultural context, well-being related terms undergo usage change across a relatively limited time span. This aspect is not surprising, if we recognize that both individuals and societies are dynamically evolving entities. The adoption of a static perspective to describe their features and functioning patterns - including well-being facets - is not only conceptually imprecise, but it may also become problematic in applied contexts, when used to design intervention programs or long-term policies.

\section{Appendix: Search Strings}

$\underline{\text { Affective words, positive affect: }}$ 
Nyte OR nyter OR nyde OR nyder ANDNOT godt av ANDNOT tillit ANDNOT respekt ANDNOT anseelse ANDNOT alkohol (enjoy);

Lykke ANDNOT lykke til ANDNOT til lykke (happiness);

Lykkelig* (happy);

Glad (joyful/experiencing happy feelings);

Glede (joy/feeling of happiness);

God*følel* OR positi*følel* (good / positive feelings);

Interesse* ANDNOT børs* ANDNOT aksje* ANDNOT invest* andnot interessert $i$ (interest);

Interessert $i$ (interested in).

\section{$\underline{\text { Affective words, negative affect }}$}

Sinne ANDNOT noen sinne (anger);

Sint OR sinte (angry);

Redd; (frightened);

Sorg* (grief);

Vond $^{*}$ følel* OR negati* følel* (negative / bad feelings);

Trist OR triste (sad);

Skam (shame);

Lei ?eg (upset).

Evaluative words (8)

Fornøyd* (contented/satisfied);

Godt liv OR gode liv (good life);

Livskvalitet* (quality of life);

Positive tanker OR tenk* positiv* (positive thoughts/ think positive);

Tilfreds (satisfied);

Tilfredshet* (satisfaction);

Tilfreds med livet OR tilfredshet med livet OR livstilfredshet (satisfied with life / life satisfaction);

Velvore (well-being).

$\underline{\text { Functional words }}$

Indre ro OR ro i sjel* OR ro i sinn* OR sinnsro (inner calmness);

URL: http:/mc.manuscriptcentral.com/rpos Email: journalpospsych@ucdavis.edu 
Mestr* ANDNOT mestring* (master);

Mestring* (mastery);

Meningsfull* (meaningful);

Meningsfylt* (meaning-filled [alternative term]);

Motivasjon* OR motivert* (motivation);

Selvutvik* OR utvikl* ? eg selv (self-development);

Selvrealiser* OR realiser* ? eg selv (self-realization).

Virtue words (7)

Modig* ANDNOT Modigliani; (courageous);

Takknem* ANDNOT død* ANDNOT nekro* ANDNOT bortgang* ANDNOT minne* ANDNOT miste* (gratitude);

Håp OR håb (hope);

Menneskelig* ANDNOT menneskelignen* (humanity);

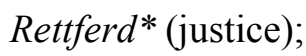

Måtehold* (temperance);

Klokskap* OR kløkt* OR visdom*OR klokhet* (wisdom).

URL: http:/mc.manuscriptcentral.com/rpos Email: journalpospsych@ucdavis.edu 


\section{References}

Aaberge, R., \& Atkinson, A. B. (2010). Top incomes in Norway. In A. B. Atkinson \& T. Piketty (Eds.), Top Incomes: A Global Perspective (pp. 448-481). Oxford: Oxford University Press.

Andersson, M. (2012). The debate about multicultural Norway before and after 22 July 2011. Identities, 19(4), 418-427. doi: 10.1080/1070289X.2012.684442

Bakhtin, M. M. (1981). The dialogic imagination: Four essays (M. Holquist Ed.). Austin: University of Texas Press.

Barstad, A. (2014). Levekår og livskvalitet: Vitenskapen om hvordan vi har det Oslo: Cappelen Damm akademisk.

Beck, U., \& Beck-Gernsheim, E. (2002). Individualization. London: Sage.

Billig, M. (1991). Ideology and opinions: Studies in rhetorical psychology. London: Sage.

Billig, M. (1997). Discursive, rhetorical and ideological messages. In C. McGarty \& S. A. Haslam (Eds.), The message of social psychology (pp. 36-53). Oxford: Blackwell.

Billig, M. (2006). A psychoanalytic discursive psychology: From consciousness to unconsciousness. Discourse Studies, 8(1), 17-24. doi: 10.1177/1461445606059546

Blakar, R. M. (1979). Language as a means of social power. In R. Rommetveit \& R. M. Blakar (Eds.), Studies of language, thought and verbal communication (pp. 109-146). London: Academic Press.

Bruner, J. S. (1990). Acts of meaning. Cambridge, MA: Harvard University Press.

Carlquist, E., Nafstad, H. E., \& Blakar, R. M. (2007). Community psychology in a Scandinavian welfare society: The case of Norway. In S. M. Reich, M. Riemer, I. Prilleltensky, \& M. Montero (Eds.), International Community Psychology (pp. 282-298). New York: Springer.

Castells, M. (2010). Communication power: Mass communication, mass self-communication, and power relationships in the network society. In J. Curran (Ed.), Media and society (pp. 3-17). London: Bloomsbury Academic.

Csikszentmihalyi, M., \& Nakamura, J. (2011). Positive psychology: Where did it come from, where is it going. In K. M. Sheldon, T. B. Kashdan, \& M. F. Steger (Eds.), Designing positive psychology: Taking stock and moving forward (pp. 3-8). Oxford: Oxford University Press.

Delle Fave, A., Brdar, I., Freire, T., Vella-Brodrick, D., \& Wissing, M. P. (2011). The eudaimonic and hedonic components of happiness: Qualitative and quantitative findings. Social Indicators Research, 100(2), pp. doi: 10.1007/s11205-010-9632-5

Diener, E. (2000). Subjective well-being: The science of happiness and a proposal for a national index. American Psychologist, 55(1), 34-43. doi: 10.1037/0003-066x.55.1.34

Diener, E., Lucas, R. E., Schimmack, U., \& Helliwell, J. F. (2009). Well-being for public policy. New York: Oxford University Press.

Diener, E., Wirtz, D., Biswas-Diener, R., Tov, W., Kim-Prieto, C., Choi, D.-w., \& Oishi, S. (2009). New measures of well-being. In E. Diener (Ed.), Assessing well-being: The collected works of Ed Diener (pp. 247-266). Dordrecht: Springer.

Dolan, P., \& Metcalfe, R. (2012). Measuring subjective wellbeing: Recommendations on measures for use by national governments. Journal of Social Policy, 41(02), 409-427. doi: $10.1017 /$ S0047279411000833

Duncan, G. (2010). Should happiness-maximization be the goal of government? Journal of Happiness Studies, 11(2), 163-178. doi: 10.1007/s10902-008-9129-y

Eckersley, R. (2000). The mixed blessings of material progress: Diminishing returns in the pursuit of happiness. Journal of Happiness Studies, 1(3), 267-292. doi: 10.1023/a:1010040010239 
Ellingsæter, A. L., \& Leira, A. (2006). Politicising parenthood in Scandinavia: Gender relations in welfare states. Bristol: Policy Press.

Eriksen, T. H. (1993). Being Norwegian in a shrinking world: Reflections on Norwegian identity. In A. C. Kiel (Ed.), Continuity and change: Aspects of contemporary Norway (pp. 11-38). Oslo: Universitetsforlaget.

Fairclough, N. (2013). Critical discourse analysis: The critical study of language. Abingdon: Taylor \& Francis.

Gooskens, C. (2005). How well can Norwegians identify their dialects? Nordic Journal of Linguistics, 28(01), 37-60. doi: 10.1017/S0332586505001319

Gough, I. (2004). Human well-being and social structures: Relating the universal and the local. Global Social Policy, 4(3), 289-311. doi: 10.1177/1468018104047489

Greco, M., \& Stenner, P. (2013). Happiness and the art of life: Diagnosing the psychopolitics of wellbeing. Health, Culture and Society, 5(1), 1-19. doi: 10.5195/hcs.2013.147

Gullestad, M. (1991). The transformation of the Norwegian notion of everyday life. American Ethnologist, 18(3), 480-499. doi: 10.1525/ae.1991.18.3.02a00040

Hellevik, O. (2008). Jakten på den norske lykken. Norsk Monitor 1985-2007. Oslo: Universitetsforlaget.

Inglehart, R., \& Welzel, C. (2005). Modernization, cultural change, and democracy: The human development sequence. Cambridge: Cambridge University Press.

Jaworski, A. (2007). Language in the media: Authenticity and othering. In S. Johnson \& A. Ensslin (Eds.), Language in the media: Representations, identities, ideologies (pp. 271-280). London: Continuum.

Jensen, L. C., \& Hønneland, G. (2011). Framing the high north: Public discourses in Norway after 2000. Acta Borealia, 28(1), 37-54. doi: 10.1080/08003831.2011.575659

Jones, M. (2008). The "Two Landscapes" of North Norway and the "Cultural Landscape" of the South. In M. Jones (Ed.), Nordic landscapes: Region and belonging on the northern edge of Europe (pp. 283-299). Minneapolis: University of Minnesota Press.

Joseph, S. (2015). Applied positive psychology 10 years on. In S. Joseph (Ed.), Positive psychology in practice: Promoting human flourishing in work, health, education and everyday life (pp. 1-6). Hoboken: Wiley.

Kahneman, D. (1999). Objective happiness. In D. Kahneman, E. Diener, \& N. Schwartz (Eds.), Wellbeing: The foundations of hedonic psychology (pp. 3-25). New York: Russell Sage.

Kashdan, T. B., \& Steger, M. F. (2011). Challenges, pitfalls, and aspirations for positive psychology. In K. M. Sheldon, T. B. Kashdan, \& M. F. Steger (Eds.), Designing positive psychology: Taking stock and moving forward (pp. 9-24). Oxford: Oxford University Press.

Kesebir, P., \& Kesebir, S. (2012). The cultural salience of moral character and virtue declined in twentieth century America. Journal of Positive Psychology, 7(6), 471-480. doi: 10.1080/17439760.2012.715182

Leontiev, D. A. (2013). Personal meaning: A challenge for psychology. Journal of Positive Psychology, 8(6), 459-470. doi:10.1080/17439760.2013.830767

Lolle, H. L., \& Andersen, J. G. (2015). Measuring happiness and overall life satisfaction: A Danish survey experiment on the impact of language and translation problems. Journal of Happiness Studies, 1-14. doi: 10.1007/s10902-015-9646-4

Lu, L. (2008). Culture, self, and subjective well-being: Cultural psychological and social change perspectives. Psychologia, 51(4), 290-303. doi: 10.2117/psysoc.2008.290

Madsen, O. J. (2015). Optimizing the self: Social representations of self-help. Hove: Routledge.

Mathews, G., \& Izquierdo, C. (2008). Anthropology, happiness and well-being. In G. Mathews \& C. Izquierdo (Eds.), Pursuits of happiness: Well-being in anthropological perspective (pp. 1-19). Oxford, NY: Berghahn Books.

McCombs, M., \& Reynolds, A. (2009). How the news shapes our civic agenda. In J. Bryant \& M. B. Oliver (Eds.), Media effects: Advances in theory and research (pp. 1-16). New York: Routledge. 
Nafstad, H. E. (2015). Positive psychology: Historical, philosophical, and epistemological perspectives. In S. Joseph (Ed.), Positive psychology in practice: Promoting human flourishing in work, health, education and everyday life (pp. 9-30). Hoboken: Wiley.

Nafstad, H. E., Blakar, R. M., Botchway, A., Bruer, E. S., Filkukova, P., \& Rand-Hendriksen, K. (2013). Communal values and individualism in our era of globalization: A comparative longitudinal study of three different societies. In H. H. Knoop \& A. Delle Fave (Eds.), Well-Being and Cultures (pp. 51-69). Dordrecht: Springer Netherlands.

Nafstad, H. E., Blakar, R. M., Carlquist, E., Phelps, J. M., \& Rand-Hendriksen, K. (2007). Ideology and power: The influence of current neo-liberalism in society. Journal of Community \& Applied Social Psychology, 17(4), 313-327. doi: 10.1002/casp.931

Nafstad, H. E., Blakar, R. M., Carlquist, E., Phelps, J. M., \& Rand-Hendriksen, K. (2009). Globalization, neo-liberalism and community psychology. American Journal of Community Psychology, 43(1), 162-175. doi: 10.1007/s10464-008-9216-6

Nafstad, H. E., Blakar, R. M., \& Rand-Hendriksen, K. (2009). The spirit of society and the virtue of gratitude: A study of changing societal ideologies of gratitude. In T. Freire (Ed.), Understanding positive life: Research and practice on positive psychology (pp. 285-302). Lisboa: Climepsi.

Nafstad, H. E., Carlquist, E., \& Blakar, R. M. (2012). Towards a psychology for a humankind and a planet under multiple threats: A social psychology of ideology. In J. P. Valentim (Ed.), Societal approaches in social psychology (pp. 61-80). Bern: Peter Lang Publishing.

Oishi, S., Graham, J., Kesebir, S., \& Galinha, I. C. (2013). Concepts of happiness across time and cultures. Personality and Social Psychology Bulletin, 39(5), 559-577. doi: $10.1177 / 0146167213480042$

Pavot, W., \& Diener, E. (2008). The Satisfaction With Life Scale and the emerging construct of life satisfaction. Journal of Positive Psychology, 3(2), 137-152. doi: 10.1080/17439760701756946

Pennebaker, J. W., Mehl, M. R., \& Niederhoffer, K. G. (2003). Psychological aspects of natural language use: Our words, our selves. Annual Review of Psychology, 54(1), 547-577. doi: 10.1146/annurev.psych.54.101601.145041

Perrons, D. (2004). Globalization and social change: People and places in a divided world. London: Routledge.

Perse, E. M. (2001). Media effects and society. Mahwah: Lawrence Erlbaum.

Peterson, C., \& Seligman, M. E. P. (2004). Character strengths and virtues: A handbook and classification. New York: Oxford University Press.

Pflug, J. (2009). Folk theories of happiness: A cross-cultural comparison of conceptions of happiness in Germany and South Africa. Social Indicators Research, 92(3), 551-563. doi: 10.1007/s11205-008-9306-8

Phelps, J. M., Blakar, R. M., Carlquist, E., Nafstad, H. E., \& Rand-Hendriksen, K. (2012). Symbolic boundaries and ideology in the Norwegian multicultural society: A longitudinal study of public discourse. Journal of Community \& Applied Social Psychology, 22(3), 187-205. doi: 10.1002/casp.1126

Polkinghorne, D. E. (2000). Psychological inquiry and the pragmatic and hermeneutic traditions. Theory \& Psychology, 10(4), 453-479. doi: 10.1177/0959354300104002

Rommetveit, R. (2003). On the role of "a psychology of the second person" in studies of meaning, language, and mind. Mind, Culture, and Activity, 10(3), 205-218. doi: 10.1207/s15327884mca1003_3

Ryan, R. M., \& Deci, E. L. (2000). Self-determination theory and the facilitation of intrinsic motivation, social development, and well-being. American Psychologist, 55(1), 68-78. doi: 10.1037/0003066X.55.1.68

Ryan, R. M., \& Huta, V. (2009). Wellness as healthy functioning or wellness as happiness: The importance of eudaimonic thinking (response to the Kashdan et al. and Waterman discussion). Journal of Positive Psychology, 4(3), 202-204. doi: 10.1080/17439760902844285 
Ryff, C. D., \& Singer, B. (2008). Know thyself and become what you are: A eudaimonic approach to psychological well-being. Journal of Happiness Studies, 9(1), 13-39. doi: 10.1007/s10902-0069019-0

Schwartz, B. (2000). Self-determination: The tyranny of freedom. American Psychologist, 55(1), 79-88. doi: 10.1037/0003-066X.55.1.79

Sejersted, F., \& Adams, M. B. (2011). The age of social democracy: Norway and Sweden in the twentieth century. Princeton: Princeton University Press.

Seligman, M. E. P. (2011). Flourish: A visionary new understanding of happiness and well-being. New York: Free Press.

Seligman, M. E. P., \& Pawelski, J. O. (2003). Positive psychology: FAQS. Psychological inquiry, 159-163. doi: 10.1207/S15327965PLI1402_03

Shah, D. V., McLeod, D. M., Gotlieb, M. R., \& Lee, N.-J. (2009). Framing and agenda setting. In R. L. Nabi \& M. B. Oliver (Eds.), The Sage handbook of media processes and effects (pp. 83-98). Thousand Oaks: Sage.

Sirgy, M. J. (2012). The psychology of quality of life: Hedonic well-being, life satisfaction, and eudaimonia. Dordrecht: Springer Science+Business Media.

Sointu, E. (2005). The rise of an ideal: Tracing changing discourses of wellbeing. The Sociological Review, 53(2), 255-274. doi: 10.1111/j.1467-954X.2005.00513.x

Steger, M. F., Shin, J. Y., Shim, S., \& Fitch-Martin, A. (2013). Is meaning in life a flagship indicator of well-being? In A. S. Waterman (Ed.), The best within us: Positive psychology perspectives on eudaimonia (pp. 159-182). Washington: American Psychological Association.

Tekstlab. (2015). The Text Laboratory. Retrieved from http://www.hf.uio.no/iln/english/about/organization/textlaboratory/services/frequency.html

Tiberius, V. (2004). Cultural differences and philosophical accounts of well-being. Journal of Happiness Studies, 5(3), 293-314. doi: 10.1007/s10902-004-8791-y

Tiberius, V. (2013). Recipes for a good life: Eudaimonism and the contribution of philopsophy. In A. S. Waterman (Ed.), The best within us: Positive psychology perspectives on eudaimonia (pp. 1938). Washington: American Psychological Association.

Tov, W., \& Diener, E. (2007). Culture and subjective well-being. In S. Kitayama \& D. Cohen (Eds.), Handbook of cultural psychology (pp. 691-713). New York: Guilford.

Twenge, J. M., Campbell, W. K., \& Gentile, B. (2013). Changes in pronoun use in American books and the rise of individualism, 1960-2008. Journal of Cross-Cultural Psychology, 44(3), 406-415. doi: $10.1177 / 0022022112455100$

Türken, S., Nafstad, H. E., Blakar, R. M., \& Roen, K. (2015). Making sense of neoliberal subjectivity: A discourse analysis of media language on self-development. Globalizations, 1-15. doi: 10.1080/14747731.2015.1033247

Uchida, Y., Norasakkunkit, V., \& Kitayama, S. (2004). Cultural constructions of happiness: Theory and emprical evidence. Journal of Happiness Studies, 5(3), 223-239. doi: 10.1007/s10902-004$8785-9$

Valsiner, J. (2007). Culture in minds and societies: Foundations of cultural psychology New Delhi: Sage.

Verschueren, J. (2012). Ideology in language use: Pragmatic guidelines for empirical research. Cambridge: Cambridge University Press.

Wagner, W. (2007). Vernacular science knowledge: Its role in everyday life communication. Public Understanding of Science, 16(1), 7-22. doi: 10.1177/0963662506071785

Watson, D., Clark, L. A., \& Tellegen, A. (1988). Development and validation of brief measures of positive and negative affect: The PANAS scales. Journal of Personality and Social Psychology, 54(6), 1063-1070. doi: 10.1037/0022-3514.54.6.1063

Wierzbicka, A. (2004). 'Happiness' in cross-linguistic \& cross-cultural perspective. Daedalus, 133(2), 34-43. doi: 10.1162/001152604323049370

Wierzbicka, A. (2009). Language and metalanguage: Key issues in emotion research. Emotion Review, 1(1), 3-14. doi: 10.1177/1754073908097175 
Wittgenstein, L. (1953). Philosophical investigations. Oxford: Basil Blackwell.

Wollebæk, D., \& Strømsnes, K. (2008). Voluntary associations, trust, and civic engagement: A multilevel approach. Nonprofit and Voluntary Sector Quarterly, 37(2), 249-263. doi: 10.1177/0899764007304754

Wong, P. T. P. (2012). Towards a dual-systems mode of what makes life worth living. In P. T. P. Wong (Ed.), The human quest for meaning: theories, research, and applications (pp. 3-22). New York: Routledge.

Yen, J. (2010). Authorizing happiness: Rhetorical demarcation of science and society in historical narratives of positive psychology. Journal of Theoretical and Philosophical Psychology, 30(2), 67-78. doi: 10.1037/a0019103

$\emptyset$ stbye, H. (2007). The Norwegian media landscape. In G. Terzis (Ed.), European media governance: National and regional dimensions (pp. 157-169). Bristol: Intellect Books.

URL: http:/mc.manuscriptcentral.com/rpos Email: journalpospsych@ucdavis.edu 
Table 1. Frequency of occurrence, affect words. Average annual occurrence across newspapers, and estimated mean annual change (EMAC) in each newspaper, adjusted for baselines.

\begin{tabular}{|c|c|c|c|c|c|}
\hline \multirow[t]{2}{*}{ Search term } & \multirow{2}{*}{$\begin{array}{c}\text { Average } \\
\text { annual } \\
\text { occurrence }\end{array}$} & \multicolumn{4}{|c|}{ EMAC (\%) } \\
\hline & & Aftenposten & $\begin{array}{l}\text { Bergens } \\
\text { Tidende }\end{array}$ & Nordlys & $\begin{array}{c}\text { Verdens } \\
\text { Gang }\end{array}$ \\
\hline \multicolumn{6}{|l|}{ Positive affect } \\
\hline Enjoy & 1196 & $2.28 * * *$ & $1.38 * * *$ & $5.24 * * *$ & $2.61 * * *$ \\
\hline Happiness & 604 & $0.88 * * *$ & $1.10 * *$ & $2.41 * * *$ & -0.34 \\
\hline Happy & 1647 & -0.36 & 0.35 & 0.17 & $-1.79 * * *$ \\
\hline Interest & 7135 & $-1.73 * * *$ & $-1.37 * * *$ & $-0.90 * * *$ & $-0.77 * * *$ \\
\hline Interested in & 2395 & $-1.63 * * *$ & $-1.73 * * *$ & $-2.81 * * *$ & $-2.69 * * *$ \\
\hline Joy & 4007 & $-1.08 * * *$ & $-1.38 * * *$ & $1.58 * * *$ & $-1.09 * *$ \\
\hline Joyful & 5773 & $0.72 * *$ & $0.97 * * *$ & $3.15^{* * *}$ & $0.54 * * *$ \\
\hline $\begin{array}{l}\text { Positive / good } \\
\text { feelings }\end{array}$ & 274 & $2.06^{* * *}$ & $1.32 * * *$ & $4.50 * * *$ & $2.65 * * *$ \\
\hline \multicolumn{6}{|l|}{ Negative affect } \\
\hline Anger & 539 & 0.20 & 0.34 & 0.78 & -0.44 \\
\hline Angry & 1129 & $1.36 * * *$ & $0.99 * *$ & 2.89 & -0.57 \\
\hline Frightened & 3317 & 0.25 & -0.37 & $-0.84 * * *$ & $-0.87 * * *$ \\
\hline Grief & 1522 & 0.43 & 0.81 & 0.20 & 0.45 \\
\hline $\begin{array}{l}\text { Negative / bad } \\
\text { feelings }\end{array}$ & 59 & $2.25^{* * *}$ & 1.31 & 2.58 & $3.75 * * *$ \\
\hline Sad & 2005 & $2.45 * * *$ & $2.20 * * *$ & $4.19 * * *$ & $1.56 * * *$ \\
\hline Shame & 620 & $1.58 * * *$ & 1.08 & $2.64 * * *$ & -1.30 \\
\hline Upset & 706 & $1.99 * * *$ & $2.01 * * *$ & $1.77 * *$ & $1.95 * * *$ \\
\hline
\end{tabular}


Table 2. Frequency of occurrence, evaluative words. Average annual occurrence across newspapers, and estimated mean annual change (EMAC) in each newspaper, adjusted for baselines.

\begin{tabular}{lccccc}
\hline Search term & $\begin{array}{c}\text { Average. } \\
\text { annual } \\
\text { occurrence }\end{array}$ & Aftenposten & $\begin{array}{c}\text { Bergens } \\
\text { Tidende }\end{array}$ & Nordlys & $\begin{array}{c}\text { Verdens } \\
\text { Gang }\end{array}$ \\
\cline { 3 - 6 } & 6567 & -0.80 & 0.01 & $1.48^{* * *}$ & 0.19 \\
\hline Contented & 57 & $1.93^{* *}$ & 1.56 & $4.41^{* * *}$ & $3.01^{* * *}$ \\
Positive thoughts & 632 & $-5.16^{* * *}$ & $-5.40^{* * *}$ & $-1.48^{* *}$ & $-2.62^{* * *}$ \\
Satisfied & 191 & $-4.22^{* * *}$ & $-2.92^{* * *}$ & $-2.72^{* * *}$ & $-2.39^{* * *}$ \\
Satisfaction & 22 & 2.88 & $8.30^{* * *}$ & -6.09 & -0.67 \\
Satisfied with life & & & & & \\
/ life satisfaction & 278 & $2.97 * * *$ & $2.08^{* *}$ & $3.80^{* *}$ & 0.75 \\
Good life & 347 & 0.56 & $3.00^{* * *}$ & $2.77^{* * *}$ & $2.86^{* * *}$ \\
Quality of life & 162 & 1.14 & 0.34 & $4.51^{* * *}$ & $3.56^{* * *}$ \\
Well-being (lit.) & & & &
\end{tabular}


Table 3. Frequency of occurrence, functional words. Average annual occurrence across newspapers, and estimated mean annual change (EMAC) in each newspaper, adjusted for baselines.

\begin{tabular}{lccccc}
\hline Search term & $\begin{array}{c}\text { Average } \\
\text { annual } \\
\text { occurrence }\end{array}$ & Aftenposten & $\begin{array}{c}\text { Bergens } \\
\text { Tidende }\end{array}$ & Nordlys & $\begin{array}{c}\text { Verdens } \\
\text { Gang }\end{array}$ \\
\cline { 3 - 6 } & 94 & $-2.09^{* * *}$ & -1.33 & $-2.65^{* *}$ & -1.13 \\
Inner calmness & 159 & $2.84^{* * *}$ & $1.57^{* * *}$ & 1.70 & $4.70^{* * *}$ \\
Meaningful & 202 & $-3.17^{* * *}$ & -0.44 & $-2.11^{* * *}$ & $-1.70^{* *}$ \\
Meaning-filled & 781 & $-1.42^{* * *}$ & $-1.89^{* * *}$ & 0.54 & 0.03 \\
Master & 157 & $10.13^{* * *}$ & $12.11^{* * *}$ & $13.78^{* * *}$ & $12.58^{* * *}$ \\
Mastery & 1307 & $3.73^{* * *}$ & $3.94^{* * *}$ & $3.18^{* * *}$ & $5.01^{* * *}$ \\
Motivation & 62 & $5.34^{* * *}$ & $4.57^{* * *}$ & 2.40 & $6.02^{* * *}$ \\
Self-realization & 41 & $3.09^{* * *}$ & $2.46^{* * *}$ & $5.01^{* * *}$ & $4.46^{* * *}$ \\
Self-development & 41 & & & & \\
\hline$* * \mathrm{p}<.01$ & & & & & \\
$* * * \mathrm{p}<.001$ & & & & &
\end{tabular}


Table 4. Frequency of occurrence, virtue words. Average annual occurrence across newspapers, and estimated mean annual change (EMAC) in each newspaper, adjusted for baselines.

\begin{tabular}{lccccc}
\hline Search term & $\begin{array}{c}\text { Average } \\
\text { annual } \\
\text { occurrence }\end{array}$ & Aftenposten & $\begin{array}{c}\text { Bergens } \\
\text { Tidende }\end{array}$ & Nordlys & $\begin{array}{c}\text { Verdens } \\
\text { Gang }\end{array}$ \\
\cline { 3 - 6 } & 553 & $2.69^{* * *}$ & $2.15^{* * *}$ & $3.41^{* * *}$ & 0.59 \\
Courageous & 497 & $2.21^{* *}$ & $2.44^{* * *}$ & $5.05^{* * *}$ & $1.73^{* * *}$ \\
Gratitude & 3864 & $-1.59^{* * *}$ & $-1.25^{* * *}$ & 0.94 & $-1.08^{* * *}$ \\
Hope & 1474 & $-1.85^{* * *}$ & -0.50 & $-1.79^{* * *}$ & $-1.22^{* * *}$ \\
Humanity & 1616 & 0.09 & $0.85^{* *}$ & -1.20 & -0.57 \\
Justice & 76 & $-2.08^{* * *}$ & $1.91^{* *}$ & -4.02 & -1.69 \\
Temperance & 850 & 0.38 & 0.17 & $3.92^{* * *}$ & -0.87 \\
Wisdom & & & & &
\end{tabular}

$* * \mathrm{p}<.01$

$* * * \mathrm{p}<.001$ 